\title{
Biudžeto apribojimo koncepcija ir ūkių finansinis išsekimas
}

\author{
Vaida Stulpinienè \\ Aleksandro Stulginskio universitetas, \\ Studentug. 11, \\ LT-53361 Akademija, Kauno r. \\ El.paštas:v.stulpiniene@gmail.com
}

\begin{abstract}
Straipsnyje pateikiama biudžeto apribojimo koncepcija, atskleidžiant biudžeto apribojimo sąsajas su ūkių finansiniu išsekimu. Ūkių ir kitų verslo organizacijų biudžeto apribojimai gali būti minkšti arba kieti, todèl straipsnyje analizuojamos biudžeto apribojimą minkštinančios priemonès (subsidijos, mokesčiai, kreditavimo sąlygos) bei minkšto / kieto biudžeto indikatoriai. Straipsnyje aptariamas biudžeto apribojimo koncepcijos aktualumas žemès ūkyje. Finansinis išsekimas atsiranda tada, kai ūkis negali ịvykdyti ịsipareigojimų, dèl to priverstas parduoti turtą, atleisti dalị darbuotojų, kreditoriai nebeturi perspektyvų atgauti investicijų arba atsiskaitymai su kreditoriais gali būti vykdomi komplikuotai. Biudžeto apribojimo koncepcijos pagrindu pateikiamos finansiškai išsekusių ūkių egzistavimo prielaidos.
\end{abstract}

Raktažodžiai: biudžeto apribojimas, finansinis išsekimas, ūkiai

\section{IVADAS}

Biudžeto apribojimo koncepciją pasiūlè vengrų mokslininkas Janus Kornai (1979), tirdamas socialistinès ekonomikos neefektyvumą. Finansinès pagalbos problematika ir jos ekonominès pasekmès tradiciškai buvo tiriamos dèl valdžios ịtakos pramonès ir bankų sistemoms. Tačiau mokslininkai pastebi, kad minkštas biudžeto apribojimas gali būti dar aktualesnis žemès ūkyje, nes valdžios institucijos teikia paramą ūkiams, pajamos iš žemès ūkio veiklos apmokestinamos diferencijuotai bei ūkiams taikomos lengvatinès kreditavimo sąlygos.

Nepaisant to, šiuolaikineje verslo aplinkoje ūkiams sun$\mathrm{ku}$ išvengti finansinio išsekimo. Plètojant verslą, ūkio veiklos pusiausvyrą gali trikdyti tiek išorinè, tiek vidinè aplinka. Mažejantys šalies ekonomikos augimo tempai, didejanti infliacija, sutrikę ūkio pinigų srautai ir vėluojantys atsiskaitymai gali sukelti jo finansinị išsekimą.

Didžiausias mokslinis įdirbis šioje srityje - Janus Kornai (1979-2010), kurio tyrimai tapo pagrindu kitiems tyrëjams. Mokslininkai Dewatripont, Maskin (1995, 2000), Qian, Roland (1998, 2000), Kornai, Maskin, Roland (2003), Konings, Vandenbussche (2004), Robinson, Torvik (2006) siekè paaiškinti minkšto biudžeto apribojimo fenomeną. Rodden, Eskeland, Litvack (2003) analizavo kieto biudžeto apribojimo koncepciją. Rizov $(2003,2008)$ tyrè kapitalo struktūros formavimą ir biudžeto apribojimo ịtaką kapitalo struktūrai, Lerman $(2004,2008)$ tyrè ūkių biudžetų apribojimus socialistiniu ir pereinamuoju laikotarpiais.
Pasigendama mokslinių tyrimų, kuriuose mokslininkai siektų atskleisti biudžeto apribojimo koncepcijos sąsajas su ūkio finansiniu išsekimu. Aktualus klausimas - ar finansiškai išsekę ūkiai (t. y. veikiantys pagal minkštą biudžeto apribojimą) gali netrikdydami ekonominès sistemos funkcionavimo tęsti veiklą ir nebankrutuoti.

Tyrimo objektas - ūkių biudžeto apribojimas ir finansinis išsekimas.

Tyrimų tikslas - apibrěžti biudžeto apribojimą ir atskleisti jo sąsajas su ūkių finansiniu išsekimu. Tikslui pasiekti keliami šie uždaviniai:

1. Apibrèžti biudžeto apribojimo koncepciją.

2. Ištirti ir pateikti biudžeto apribojimo sąsajas su ūkių finansiniu išsekimu.

\section{TYRIMŲ METODAI IR SĄLYGOS}

Tyrimas atliktas naudojant mokslinès literatūros loginès analizès ir sintezès, indukcijos bei palyginimo metodus.

\section{REZULTATAI IR JŲ APTARIMAS}

\section{Biudžeto apribojimo koncepcija}

Biudžeto apribojimo koncepcija buvo analizuojama socialistinèje ekonomikoje, siekta paaiškinti, kodèl įmonès dirba neefektyviai. Biudžeto apribojimai yra dažniausiai tiriami mikroekonomikos lygmeniu, nes biudžeto apribojimo terminas yra perimtas iš namų ùkio ekonomikos. Tačiau ta 
pati koncepcija gali būti adaptuota ir kitoms organizacioms, imonèms, ne pelno siekiančioms organizacijoms ir vietos valdžios institucijoms, t. y. visoms organizacijoms, gaunančioms pajamų ir patiriančioms išlaidụ.

Biudžeto apribojimo sąvoka reiškia, kad ūkis, kaip ir bet kuri kita organizacija, turi padengti savo išlaidas iš pirmini dotaciju ir pajamu. Jei ūkis to nepadaro, finansiškai išsenk todel negali išgyventi be išorinès pagalbos. Terminas todel negall isgyventi be išorines pagalbos. Terminas „apribojimas interpretuojamas kaip likvidumo, mokumo arba buskolinimo lygio riba, iki kurios toleruotinas finansinè

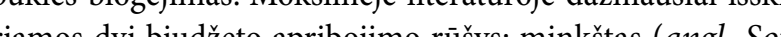
bulet constain - SBC) ir kess (angl had bof budget constraint - SBC) ir kietas (angl. hard budget constraint - HBC). Organizacija turi kietą biudzeto apribojimą tol, kol fi nega na paranos is kity organizaciju, siekiant sumazint fon apimtis arba nutraukti veiklą, jei finansinis isssekimas tęsias (Kornai, Maskin, Roland, 2003). Kietas biudžeto apribojimas reiškia, kad organizacija, kurios ișlaidos yra didesnès už jos pajamas, negales toliau veikti (Kornai, 2001).

\section{Minkštas biudžeto apribojimas}

Anot Kornai $(1980,1986)$, Breuille, Madies, Taugourdea (2007), minkštas biudžeto apribojimas siejamas su organizacijos lūkesčiais. Organizacija turi minkšstą biudžeto apribojmą, jei neprivalo ir nesistengia dirbti pelningai, jei yra tikimybè, kad bet kokiu būdu gaus finansinę pagalbą finansinio išsekimo atveju. Tikimybè finansinio išsekimo atveju gaut finansinę pagalbą neskatina organizacijos vadovụ laikytis finansinès disciplinos. Todèl minkštas biudžeto apribojima gali būti laikomas machinacija, jei organizacija ieško būdu kaip išvengti finansiniu įsipareigojimų vykdymo.

Kornai (1986) pateikè keturias biudžeto apribojimą minkštinančias priemoniu grupes. Pirmajai grupei mokslininkas priskyrè "minkštas subsidijas", kurias teikia šalie Vyriausybe ar vietos valdžia. Anot mokslininko, tos subsidijos laikomomos minkštomis, kurios gaunamos išskintinemer teisèmis, del ju gavimo galima susitarti“ ar gaunamos loJistini praeities, dabarties ar ateities išlaidu perviršio.

Antroji priemoniu grupe pasireiškia apmokestinimu.

Antroll pries ar a de

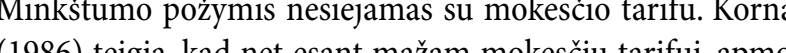

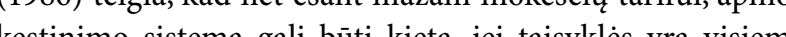

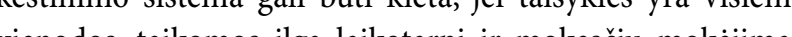
vienodos, taikomos ilgą laikotarpị ir mokescių mokèjimas yra grieztai priverstinis. Priesingai, apmokestinimas yra minkstas, net esant dideliam mokescic tarifui. Jei apmokes tinimas yra svarstytinas, dè jo galima derètis, daryti politin spaudimą. Mokesčių minkštumo požymiu yra diferencijuo mokesčiu tarifai, kurie pritaikyti skirtingiems sektoriam skirtingoms veiklos sritims ar skirtingų nuosavybès form verslo organizacijoms. Taip pat jei mokestiniu prievoliy vykdymas nera griežtas, yra istatymų spragu, numatyta specialių lengvatų, gali būti neterminuoti mokestinių prievolį̀ atidèjimai ir t. t.
Trečioji grupé apima kreditų teikimo sąlygas. Autorius eige, kad „minkštas kreditas" nesiejamas su palūkanu normos dydžiu. Kredito sistema gali būti kieta net su žem âkanų norma (jeigu kreditų rinkoje žema norma), je redito sutarties ivykdymas yra griežtai priverstinis. Kreditorius skolina pinigus, tikèdamasis savalaikio ịsipareigojim vykdymo (skolos grąžinimo), o ne teikia finansine pagalba finansiškai išsekusiam ūkiui, kuris nesugebės vykdyti skolo sipareigojimu. Spaudimas vykdyti kredito sutarties salygas ęsiasi iki sutarties pabaigos: griežtos sankcijos nemolk aveju apim

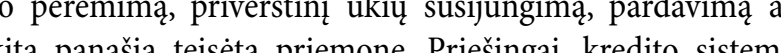
ali būti minkšta net su didelèmis palūkanom jis je

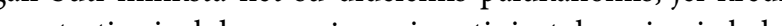
jpareigojimy nevyldymai galimi skolos atidijimai ir nafi

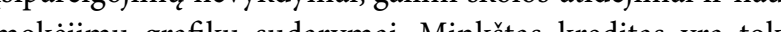
mokéjimu grafikų sudarymai. Minkštas kreditas yra toks,

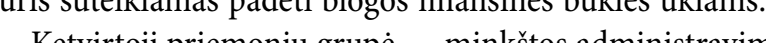
Ketvirtoji priemoniu grupe - „, minkštos administravim kainos" taikomos tuo atveju, kai kaina nustatyta biurokratines șstaigos, bet ne laisvu pardavejo ir pirkejo susitarim Administravimo kaina yra kieta, jei kaskart, išaugus išlaidoms, ji nèra keičiama. Administravimo kaina yra minkšta jei ji nustatyta lanksčiu principu ir yra beveik automatiška reguliuojama padidejus iśaidoms (Kornai, 1986).

Kaip teigia Kornai (1986), šios keturios biudžeto apribojimą minkštinančios priemonès nebūtinai turi būti suderinamos, bet nèra ir viena kitą paneigiančios. Šios priemones gali büti pritaikytos tuo paciu metu ar viena paskui kita. Pagal Kornai (1999), Dewatripont ir kt. (2000), minkšto biudžeto apribojimo tęstinumas pastebimas daugelyje perein mojo laikotarpio ekonomiku. Tačiau „minkštumas“ pasireiškia ne tiesioginèmis subsidijomis, bet netiesioginiais būdais, pavyzdžiui, mokesčiu skolomis ar lengratinemis" banko paskolomis (Konings, Rizov, Vandenbussche, 2003).

Rizov (2008), plètojantis biudžeto apribojimo idèja identifikuoja tris priemoniu grupes, rodančias minkštą biudžeto apribojim Pirmosios grupès minkštinimo priemonemis laikomos kai kurios kredito formos. Antroji grupe apima fiskalines priemones, tokias kaip subsidijos ir mokesčiai, išlaidų sumarimas ar isipareigojimu atidējimas. Trečioji - ivairūs netiesioginiai paramos būdai. Pavyzdžiui, Vyriausybè gali gelbèt akius, kurie turi pardavimo sunkumu, nustatydama prekybo pribojimus importui ir apribodama ušienio konlorecila

Negalima teigti, kad biudžeto apribojimas yra minkštas et kokiu atveju, kai ükis ar kita verslo organizacija, finansiškai išsekusi, gauna finansinę paramą. Anot Kornai (1986, minkssto biudžeto sindromas yra tada, kai toks subsidijavim vyksta dažnai, jei vadovai gali tikètis biudžetinių injekcijų

Aiškindami minkštą biudžeto apribojimą Shleifer, Vis hny (1994) nurodo valdzios teikiamas subsidijas ịmonèm kad palaikytu šalyje neefektyviai aukštą darbo lygi, tačia Segal (1998) teigia, kad minkštas biudžetas pasireiškia, je monès yra netobulai konkurencingos. Anot Segal (1998), imonés nepakankamai investuoja, palyginti su efektyvi (konkurencingų) imonių rezultatais. Perotti (1993) teigia, kad minkštą biudžeto apribojimą sạlygoja tiek socialinès, tiek asmeninės valdžios institucijų priežastys. Neefektyvia dirbančiu ūkiu biudžetu kietinimas reikštu, kad vienas bankrotas sąlygotu kitą (Janus, 2007). Todèl minkštas biudžetas yra paplitęs besivystančiose šalyse (Skoog, 2000; Raise 1997), nes valdžia yra itraukta i finansavima ir ekonominis veiklos reguliavima Valdžia investuoja kad galety wykdy politinius elon

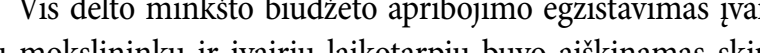
(1) optimaliu fistancin atso bedarbystes ir tęst socialint aprupinima. Naujesni tyrima

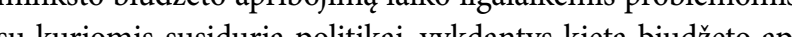
sur ribojimą (Maskin, Xu 2001; Kornai, Maskin, Roland, 2003). Pažymetina, kad politikai gauna asmenines naudos, siekdam palaikyti darbo lygi, todel kuriamos darbo vietos, kurios yra stimulas subsidijuoti įmones (Shleifer, Vishny, 1994). ,,Minkšto biudžeto apribojimo" sąvoka dabar plačiai naudojama ịvatiose ekonominese veiklose ir taikoma rinkos ekonomikoje. Kornai (2001) vaizdžiai apibūdino SBC reiškinį, teikdamas, kad SBC yra sudètingas sindromas, kuris giliai įsitvirtina ị ekonomikos politine aplinką, teisinę sistemą ir ủkio subjektu elgesí. Jei minkšti biudżeto apribojimai paplinta jie „eina“ per ekonomiką kaip vežys ir pridaro daug žalos. Sạvoka „sindromas“ paprastai reiškia būdingus simptomus, kurie išrryškèja esant ypatingoms aplinkybèms (Kornai, Maskin, Roland, 2003)

Rizov (2008) pateikia esminį SBC sindromo bruoža, kuris, anot autoriaus, yra tai, kad bet kuriuo atveju paramos priemonès yra iš anksto žinomos ir intervencija nevienkartinė. Todè ktualus ir SBC sindromo masto laipsnis. Kornai, Maskin, Roand (2003) nurodo, kad SBC sindromo matavimo esme yra iba kada organizacija gali bankrutuoti. Vienas iš variant

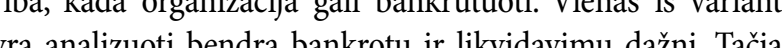
yra analizung bes iš Is is vers o on strink vertinti biudžeto apribojimo minkštumą

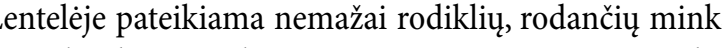
to / kieto biudžeto apribojimą, tačiau, anot Konings, Vandenbussche (2004), beveik visos verslo organizacijos, turinčio minkstą biudzeto ap rbojimą, kaip praeities komunistinio režimo palikimą, yra mažiau orientuotos rinkoje.

\section{Kietas biudžeto apribojima}

rieš perèjimą mai didžiaja dalimi susidèjo iš tiesioginių vyriausybinių subsidijų nuostolingoms imonems. Perejejmo proceso metu subsidijos dingo. Taciau tai nereišké, kad ịmonès netikètai susidūrè su kietais biudžeto apribojimais. Daug privatizuotu ir valstybini imoniu ir toliau ivairiu pavidalu gaudavo „pasleptas" subsid- jas (Schaffer, 1998). Dažniausiai minkšto biudžeto apribojimy formos pasireiškia, kai valdžia nepajegia susirinkti mokesčiu valstybiniai bankai duoda pigias paskolas ar nepajegia surin ti palükanų už paskolas (Konigns, Vandenbussche, 2003).

Kietas biudžeto apribojimas taip pat yra aptartas Korna $(1980,1986)$ darbuose. Iš esmès kietas biudžeto apribojimas yra visiško finansinio pasitikèjimo sinonimas, del kurio īkjo bankroto grèsmè yra reali. Verta pastebèti, kad biudžto apribojimo kietumas nèra pelno maksimizavimo sinonimas. Peln maksimizuojntis ükis net jei ir nera isisolines,

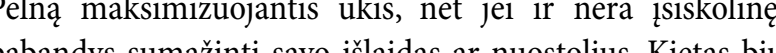
dyeto apribojimas reškia kad net jei ükis siekia labis

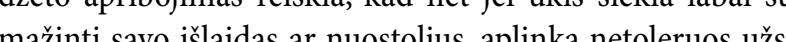

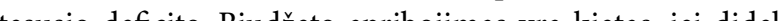

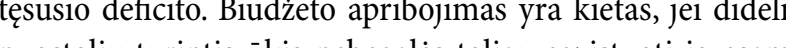
form. Tagi, lus labe forma. Tagi, ku labiau alis, turntis nuostoliu, yra apsaugotas nuo tragisikų pasekmiu, tuo minkštesnis yra biudžeto apribojimas. Viena vertus, naudos maksimizavimas siejasi sa sprendinç priemimu t̨monés viduje, kita vertus, biudžeto apribojimo minkštumas ar kietumas siejasi su išorinèm ostolių toleravimo ribomis (Kornai, 1986).

Besfamille, Lockwood (2004) teigia, kad akademinèje ir politinëje erdvèje vieningai pripažịstama, jog regionin valdžia visada pageidauja kieto biudžeto apribojimo. Ties daugelis mokslininku siekia atrasti instituciniu mechanizmų, kurie sukietintų biudžeto apribojimą

Žemès ūkio politika ir ükiu biudžeto apribojimas Bakucs, Ferto, Fogarasi (2006) pastebi, kad minkštas biudžeto apribojimas gali būti dar aktualesnis żemès ūkyje, nes valdžios institucijos rèmé ükius, besirengiančius stoti $i$ ES, kai tuo metu gamybos imonès nebuvo daug subsidijuojamos. Klasikine ekonomikos problema - kaip efektyviau paskirstyti išteklius, todèl minkštą biudžeto apribojimą turintys ūkiai laikomi neefektyviais. Kita vertus, kietą biudžeto apriboijmą turintys ūkia aikomi konkurencingais ir galinčiais uždirbti pelną Vadinasi, jei ūkis, dirbdamas neefektyviai, toliau gali egzistuoti, galim daryti prielaid a kad jis turi minkšţ̨ biudžeto apribojim not Korni (2001) jei minkštss biudžeto apribojimas vis dar viš išsekusio ūkio bankrotas ar restruktūrizavimas.

Ũkiai, priklausomai nuo jų tipo (ūkiai i tipus skirstomi paga arba naudojimo formą ir kt. kriterijuss), gali turèti skirtingus

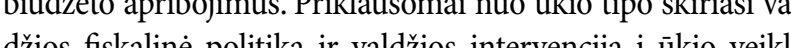
Zzios fiskaline politika ir valdzios intervencija 1 ukio veikl Siuo požiuriu svarbu atsižvelgti į tai, kad Kornai (1986), pateikdamas minkšto biudžeto koncepciją, kaip esminị veiksnị laike valdžios institucijų įtaką biudžeto apribojimo minkštumui.

Lerman, Csaki, Feder (2004) analizavo socialistinio žemess ūkio neefektyvumą ir ūkius klasifikavo pagal dydị. Autoriai teigè, kad ükių neefektyvumą lèmẻ ypač dideli ūkiai ir kolektyvinis gamybos organizavimas. Anot autoriu, central zuotai planuojama aplinka, kuri izoliavo ukius nuo rinkos signalų, nustate pagrindinius tikslus ir numate kam vartotoja 
Lentelè. Minkš̌to / kieto biudžeto apribojimo rodikliai (Kornai, Maskin, Roland, 2003)

Table. Indicators of softness / hardness of budget constrain of the firm (Kornai, Maskin, Roland, 2003)

\begin{tabular}{|c|c|}
\hline $\begin{array}{l}\text { Biudžeto apribojimo matavimas } \\
\text { The measurement of budget constraint }\end{array}$ & $\begin{array}{l}\text { Autoriai, kurie panaudojo matavimą } \\
\text { Studies applying the measurement }\end{array}$ \\
\hline \multicolumn{2}{|l|}{$\begin{array}{l}\text { "Suminkštinimo" priemonès } \\
\text { Instruments of softening }\end{array}$} \\
\hline $\begin{array}{l}\text { 1. Subsidijos arba kitos valstybės išmokos } \\
\text { Subsidies or other contributions of the state: }\end{array}$ & EBRD (1998) \\
\hline $\begin{array}{l}\text { a) dalis nuo BVP arba nuo bendro biudžeto \% } \\
\text { percentage of GDP or total budget }\end{array}$ & $\begin{array}{l}\text { Gao, Schaffer (1998) } \\
\text { Raiser (1994, 1996) }\end{array}$ \\
\hline $\begin{array}{l}\text { b) imonèms atskaitomy subsidijy procentas } \\
\text { percentage of firms reporting subsidies }\end{array}$ & $\begin{array}{l}\text { Earle, Estrin (1998) } \\
\text { EBRD (2000) }\end{array}$ \\
\hline \multicolumn{2}{|l|}{$\begin{array}{l}\text { 2. Minkšstas apmokestinimas } \\
\text { Soft taxation: }\end{array}$} \\
\hline $\begin{array}{l}\text { a) mokestines nepriemokos, kaip BVP arba bendro biudžeto dalis } \\
\text { tax arrears as a percentage of GDP or total budget }\end{array}$ & $\begin{array}{l}\text { Djankov, Kreacic (1998) } \\
\text { EBRD (1998) } \\
\text { Frydman, Gray, Hessel, Rapaczynski (2000) } \\
\text { Pinto, Drebentsov, Morozov (2000) } \\
\text { Schaffer (1998) }\end{array}$ \\
\hline $\begin{array}{l}\text { b) imoniu ataskaitiniu mokestiniu jisiskolinimy procentas } \\
\text { percentage of firms reporting tax arrears }\end{array}$ & $\begin{array}{l}\text { Sjöberg, Gang (1996) } \\
\text { EBRD (2000) }\end{array}$ \\
\hline c) tyrimas: požiüris j reiškini / survey: perception of the phenomenon. & Tóth (1998) \\
\hline \multicolumn{2}{|l|}{ 3. Minkšstas banko kreditas / Soft bank credit: } \\
\hline $\begin{array}{l}\text { a) paskirstant kredita pirmenybe teikia finansini i issekimą patiriančioms imonèms } \\
\text { preference for distressed firms in credit allocation }\end{array}$ & $\begin{array}{l}\text { Brana, Maurel, Sgard (1999) } \\
\text { Budina, Garretsen, de Jong (2000) } \\
\text { Gao, Schaffer (1998) } \\
\text { Schaffer (1998) }\end{array}$ \\
\hline $\begin{array}{l}\text { b), blogoso" paskolos (pvz., kaip bendra negražintuty paskoly procentinè dalis) } \\
\text { "bad" loans (e. g. as a percentage of total outstanding loans) }\end{array}$ & $\begin{array}{l}\text { Bonin, Schaffer (1995) } \\
\text { EBRD (1998, 1999) } \\
\text { Gao and Schaffer (1998) }\end{array}$ \\
\hline $\begin{array}{l}\text { c) uždelelsti jisiskolinimai (pvz., kaip bendra negražintu paskoly ar banko kredito ir už- } \\
\text { delsto isiskolinimo bankui santykis \%) } \\
\text { arrearrs of repaymment of loans (e. . g. as a percentage of total outstanding loans or bank } \\
\text { credit and bank arrear correlation) }\end{array}$ & $\begin{array}{l}\text { Cull and Xu (2000) } \\
\text { Dobrinsky (1994) } \\
\text { Frydman, Gray, Hessel, Rapaczynski (2000) } \\
\text { Gao and Schaffer (1999) } \\
\text { Perotti and Carare (1997) }\end{array}$ \\
\hline $\begin{array}{l}\text { d) neiprastas skolos ir nuosavo kapitalo santykis arba skolos / turto santykis } \\
\text { unusual debt/equity ratio or debt/asset ratio }\end{array}$ & $\begin{array}{l}\text { Budina, Garretsen, and de Jong (2000) } \\
\text { Majumdar (1998) } \\
\text { Gao and Schaffer (1998) }\end{array}$ \\
\hline $\begin{array}{l}\text { e) neiprastas pinigy srauty/skolos santykis } \\
\text { unusual cash-flow/debt ratio }\end{array}$ & Pohl, Anderson, Claessens, Djankov (1997) \\
\hline $\begin{array}{l}\text { f) ap̌zvalga: subjektyvus vertinimas } \\
\text { survey: subjective assessment }\end{array}$ & Tóth (1998) \\
\hline \multicolumn{2}{|l|}{ 4. Viršytas prekybos kreditas / Excess trade-credit: } \\
\hline $\begin{array}{l}\text { a) Uždelstas prekybos kreditas, kaip BVP ar bendrojo kapitalo procentas } \\
\text { overdue trade credit as a percentage of GDP or total capital }\end{array}$ & $\begin{array}{l}\text { Bonin, Schaffer (1995) } \\
\text { EBRD (1998) } \\
\text { Frydman, Gray, Hessel, Rapaczynski (2000) } \\
\text { Sjjoberg, Gang (1996) } \\
\text { Pinto, Drebentsov, Morozov (2000) } \\
\text { Schaffer (1998) }\end{array}$ \\
\hline $\begin{array}{l}\text { b) apžvalga: subjektyvus vertinimas } \\
\text { survey: subjective assessment }\end{array}$ & Tóth (1998) \\
\hline \multicolumn{2}{|l|}{ Pagalbos, lükesčiai / Expectation of rescue } \\
\hline $\begin{array}{l}\text { 5. Tyrimo duomenys apie subjektyvias tikimybes, susijussias su pagalbos lūkesč̌iais } \\
\text { Survey data about subjective probabilities concerning the expectation of rescue }\end{array}$ & Anderson, Korsun, Murrell (2000) \\
\hline \multicolumn{2}{|l|}{ Išejimo proceso savybès / Characteristics of the exit process } \\
\hline 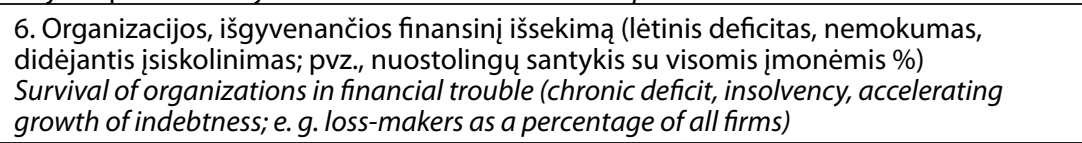 & $\begin{array}{l}\text { Claessens, Peters (1997) } \\
\text { EBRD (1998) } \\
\text { Gao, Schaffer (1998) } \\
\text { Li, Liang (1998) }\end{array}$ \\
\hline $\begin{array}{l}\text { 7. Pateiktty ir vykdomy bankroty ir likvidavimu dažnumas (pvz,y visu imoniy skaičiaus dalis) } \\
\text { Frequency of bankruptcies and liquidations, filed and executed (e. g. as percentage of total } \\
\text { number of firms) }\end{array}$ & $\begin{array}{l}\text { Bonin and Schaffer (1995) } \\
\text { EBRD (1998) } \\
\text { Mitchell (1998) }\end{array}$ \\
\hline $\begin{array}{l}\text { 8. Finansinès pagallbos dažnumas } \\
\text { Frequency of bail-outs }\end{array}$ & Li, Liang (1998) \\
\hline
\end{tabular}

astaba: lenteleje pateikti duomenys paremti tik subsidijomis aǐskiu pavidalu, kurios analizuojamos teoriškai iaškinant SBC reïkinini, ir taikyti rodikliai (kairiajame stulpelyje) matuoja biudžzto apribojimo minkšstumą/ kietumą.

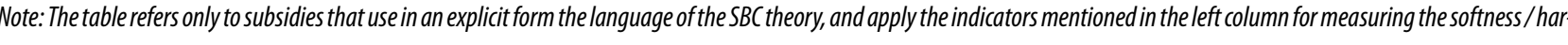
dness of the budget constraint. teikia pirmenybę. Jụ nuomone, tai buvo viena iš priežasciŭ, kodè ükiai galèjo veikti neribotą laiką pagal minkštą biudžeto apribojimą neuždirbdami jokio pelno. Vykdant agrarinę reformą buvo tikimasi, kad privačios nuosavybè ir ūkininkavimo laisves pagrindu susikurs efektyvesnè ükininkavimo sistema nei kolūkiai (Vitunskiené, 2008).

Ũkio dydis socialistinèse šalyse buvo gerokai didesnis nei vidutinis turtingos rinkos ekonomikos šalies, tokios kaip JAV ar Kanados. Dideli ūkiai pasižymi ne tik dideliais že

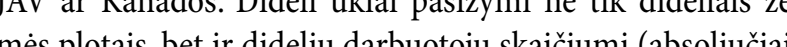
dydžiais ir vienam heltarui žemess). Tokie dideli ükiai yra

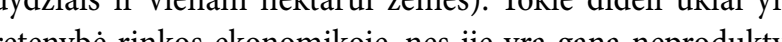

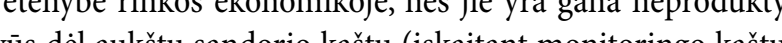

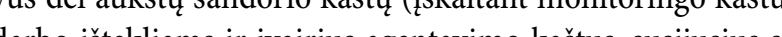

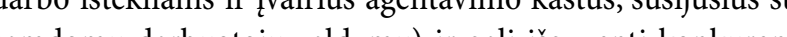
san cineje aplinkoje tik esant ypatingoms aplinkybems. Kita vertus kolükiai, kaip gamybos organizavimo forma, praktiška siandien neegzistuoja rinkos ekonomikoje dèl jiems būdingo neefektyvumo ir dẻl ịvairių vadovų elgesio ir valdymo savybių (Lerman, Csaki, Feder, 2004)

Su minetomis problemomis taip pat susiję nuosavybes teisè ir žemés mobilumas. Žemès ükio modeliui rinkos ekonomikoje būdinga individualūs arba šeimos ūkiai, bet ne kolektyvai. Individualūs arba šeimos ūkiai veikia privačioje žemëje, gali žemés valda disponuoti savo nuožiūra (Lerman, Csaki, Feder, 2004)

Žemés ūkio subsidijavimo našta buvo rimta našta valstybès biudžetui tiek socialistinèje, tiek rinkos ekonomikoje. Socialistinèje ekonomikoje ši našta buvo būtina, siekian užtikrinti gyventojams mažas maisto kainas. Lerman (2008) teigia, kad pastaraisiais metais ekonominé ir politiné aplinka pasikeitè, panaikinamos subsidijos, kurios turèjo slopinamaj poveiki, dèl to daliai ūkiụ nuostoliai išaugo. Smulkieji ūkia susiduria su visiškai skirtingais išoriniais veiksniais, susijusiais su Vyriausybés politika, kuri turi labai stipru poveiki $j$ pelningumi Be subsidiju biai yra nepelningi atsižvelgiant i dabartine gamybos struktūrą ir valdymo strategiją.

Neretai minkštas ir kietas biudžetai laikomi kontrastingais. Tačiau Kornai išskiria tarpines rūšsis tarp šiu dvieju kraštutinumu. ,Kietas“ ir „minkštas" yra dvi ekstremalio padètys griežtumo skalèje (pinigų trūkumo). Kornai (1986 2001) pripažista, kad gali egzistuoti tarpinès padètys tarp kieto ir minkšsto biudžeto apribojimo. Ši savo teigini mokslininkas argumentuoja tuo, kad vadovaujantis griežtumo skale, tik taip ar ne (minkštas ar kietas biudžeto apribojimas) visiškai neefektyvus ar visiškai efektyvus biudžeto apribojimas yra viena kitą paneigiančios galimybès. Išorinè pagalba nebūna teikiama automatiškai, todèl jai gauti taip pat yra bütinos tam tikros pastangos. Ükio vadovas (ūkininkas) a privačios įmonès savininkai turi griebtis politinio spaudimo Ir lobizmo, ieskoti asmeninių rysių. Kysininkaujant taip pa gali būti siekiama finansines paramos. Tam tikra paslèpta korupcija abipusiu paslaugu forma yra labiau paplitusi. Bet kokiu atveju, ekonominè renta ir biudžeto apribojim minkštejimas nëra nieko nekainuojantis.
Pateikiama biudžeto apribojimo kraštutinių kriteriju bendroji schema pagal Kornai (1986) aptartus biudžeto apribojimo minkštinimo būdus.

Centrinëje schemos (pav.) dalyje pateikiami biudžeto apribojimo minkštinimo būdai. Kraštutinis kietumo kriterijus subsidiju atveju yra tai, kad visiems rinkos dalyviams salygos vienodos, minkštumo kriterijus, jei subsidija gaunama derèj-mosi keliu yra svarstytina Biudžeto apriboijmas yra kietas jei mokesčiji nèra diferencijuoti, priešingu atveju jei mokesči

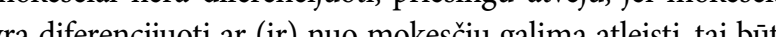
minkš̌tu požymis kietas biudžeto apribojim lai viš̌lai netolen sạlygomis: los gico paskose gro lükn chanch

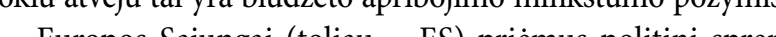
Europos Sajungai (toliau - ES) prièmus politini sprendimą del jos išplettimo ir naujų narių priemimo, Vidurio Rytų Europos šalys, tarp ju ir Lietuva, pasirinkę integravimosi $\mathfrak{i}$ Europos Bendriją (toliau - Bendrija) kelią, turejo reformuoti žemés ükio politika, kuri neatitiko ES krypčii ir reikalavimu. Lietuva ịsipareigojo prisijungti prie ES vykdomos bendrosios žemès ūkio politikos (toliau - BŽŨP) ir kartu siekti šiu tikslu:

- padidinti ES žemès ūkio produkcijos konkurencingumą (mažinant kainas)

- užtikrinti maisto saugumą ir kokybę;

užtikrinti kaimo gyventojų stabilias pajamas ir pakankamą gyvenimo lygí; skatinti žemės ūkyje paisyti aplinkosaugos reikalavimų ir didinti gyvulių gerovès standartus - ieškoti alternatyviu žemès ūkiui pajamų šaltiniu ir galimybiu isidarbinti žemdirbiams ir ju šeimu nariams (Trakelis, 2007).

ES struktūrinių fondų parama Lietuvai yra tikslinè parama siekiant didinti ükiu konkurencinguma ES struktērini fondu parama buvo skiriama žemés ūkiui ir žuvininkystei siekiant pagerinti ūkiụ struktūra paivairinti žemess ükio veikla modernizunti imones ir lt Pagal bendrojo akio veimo da crograma-

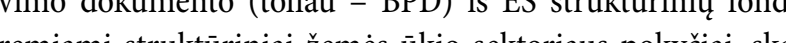
rina ra ciji konedai, pad cijai konkuruoti ES.

ES struktūrinių fondų parama galèjo pasinaudoti žemès ūkio bendrovés, kooperatinès bendrovès (kooperatyvai) ákininkai, kaimo gyventojai, kaimo bendruomenès, valstybinès institucijos ir privačios ịmonés, nevyriausybinès organizacijos, mokymo institucijos, žvejybos, akvakultūros, žuv perdirbimo įmonés, žvejai, laivų savininkai ir kitos žemes äkio sektoriui priklausančios organizacijos. ES struktūrini fondų lěšomis yra remiami žemès ūkio sektoriaus projektai kurie atitiko nurodytus prioritetus, priemones ir remtina veiklos rūšs

Bendroji žemés ükio politika ir dabar yra dèmesio centre. Trakelis (2007) teigia, kad BZZUP tikslas yra ne ekonominis 


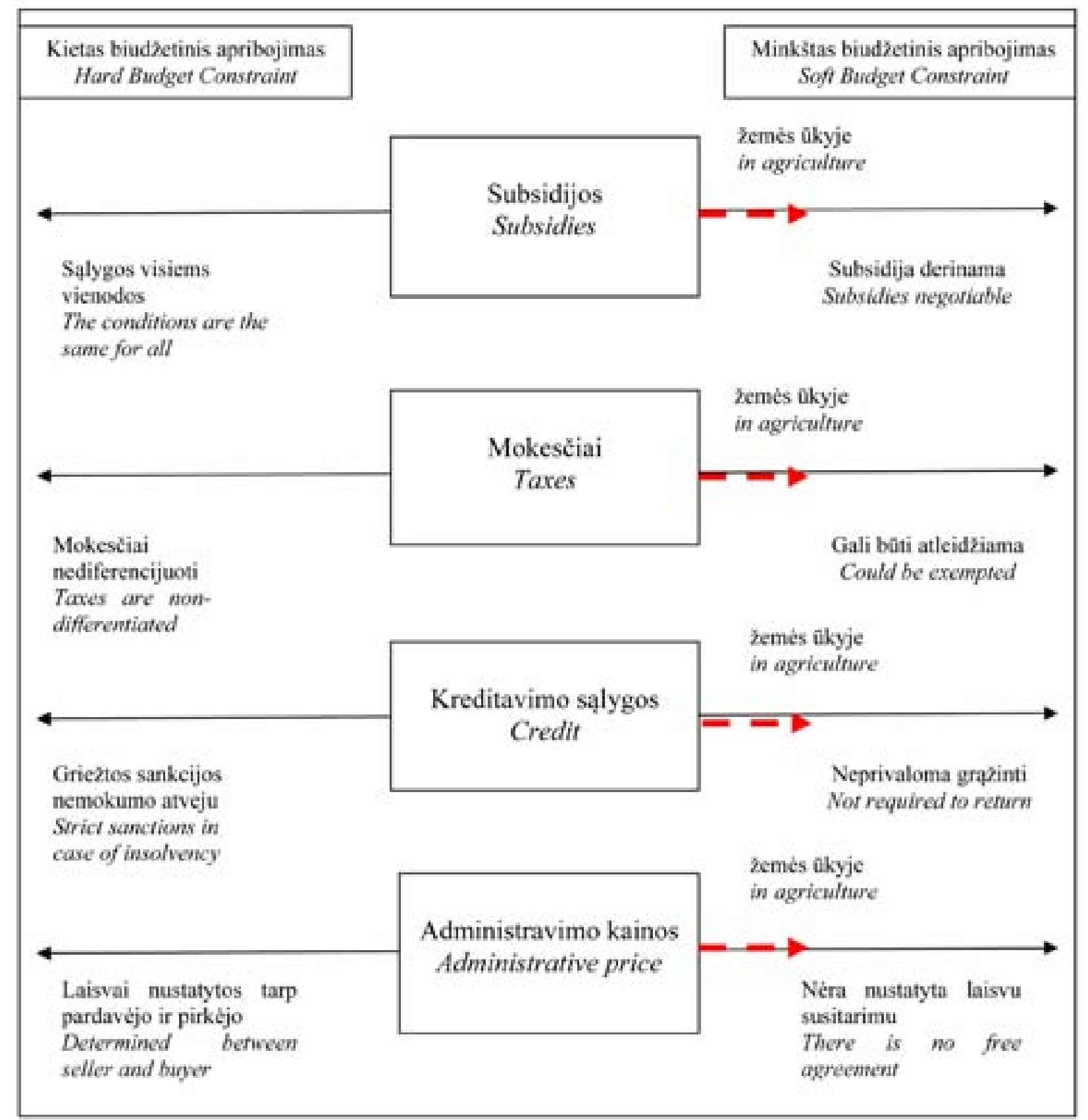

Pav. Biudžeto apribojimo kraštutiniai kriterijia (sudaryta autorés)

Figure. Budget constraint marginal criteriors (made by the author)

efektyvumas, o žemdirbiu gyvenimo lygio palaikymas. Ne paisant šio tikslo, BŽŪP finansiniai ištekliai turètų būti naudojami efektyviai.

Lietuvos kaimo plètros 2007-2013 metų programa buvo pradèta rengti nuo $2005 \mathrm{~m}$. Ji ne tik sujungè í vieną visumą 2004-2006 m. laikotarpio ES paramos investicines be kompensacines priemones, bet ir apème daug visiškai nauju tik šiam laikotarpiui būdingų, paramos priemonių ịvairiem skirtingo amžiaus kaimo žmonių poreikiams tenkinti: sudarytos palankios galimybès pasinaudoti parama smulkiesiem bei vidutiniams ūkininkams, sukurtos prielaidos kaime kurti alternatyvius verslus, puoselèti tautinị paveldą, kaimo turiz- mą, stiprinti sektoriaus konkurencingumą, tvarkyti aplinką ir kraštovaizdi, didinti kaimo gyventoju užimtumą, palaikyti ir ugdyti jų bendruomeniškumą, mažinti skirtumus tarp miesto ir kaimo bei tarp atskirų regionų ir kt. Su Europo Komisija buvo derinami esminiai, strateginiai dalykai, taciau, rengiant kiekvienos priemonès igyvendinimo taisykles, gamtinių sąlygų bei sektoriaus tradicijų savitumui. išskyrus tuos atvejus, kai parama panaudojama ne pagal paskirtị. Kadangi Europos Komisija griežtai kontroliuoja, kaip parama naudojama, todel negalima teigti, kad ES param buvo palikta erdvess savarankiškumui bei konkrečios šalie

ES skiriamos léšos yra parama, todè jụ grą̌zinti nereikia, gaunantys ūkiai turi minkštą biudžeto apribojimą dèl subsidijavimo, nes ES gali sustabdyti ar net nutraukti programos fnansavimą, nustačius netinkamus paramos naudojim atvejus.

Okininku ar kitu žemès ūkio veiklą vykdančiu gyventoju gautu pajamu iš žemés ūkio veiklos apmokestinimas Lietuvoje yra labai diferencijuotas ir mokesčiai nuolat keičiami Taikomos ivairios mokestines lengvatos ir apmokestinant remès ükio bendroves pelno mokesčiu. Tačiau finansine pa-

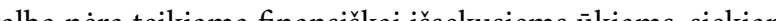

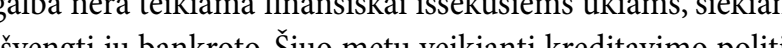

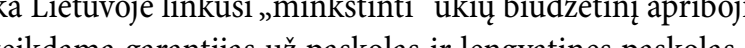

Pǎ̌metina lad f

Pažymetha, kad fansinis issel ans atsiranda tada, ka

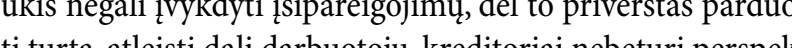
thin tyvų atgauti investici)̨̧ arba atsiskaitymai su kreditoriais gal buti vykdomi komplikuotai. Jeigu ukis ar kita verslo organizacija negali toliau egzistuoti jos esama forma, finansinis išsekimas priveda prie bankroto, likvidavimo ar esminio restruktūrizavimo. Požiuuris, kad uukis, turintis minkštą biudžeto apribojimą, negali finansiškai išsekti, yra neteisingas. Ūkis turintis minkštą biudžeto apribojimą, negali bankrutuoti. Svarbu suprasti, kad ūkis, turintis minkštą biudžeto apribojimą, finansinę injekcifą gauna tada, kai jis finansišskai isssenk Injekcija reikalinga, kad būtu išvengta neigiamų ekonominių pasekmių ir ükis galetų toliau egzistuoti jo esama forma. Mokslininkai sutaria, kad organizacijų bankrotas visuomet laikomas neigiamu rinkos ekonomikos reiškiniu, ne tik makroekonomine, bet ir socialine problema. Bankrutuojanti organizacija negali atsiskaityti su kreditoriais, priversta atleisti darbuotojus, o dell to didejja nedarbas, išauga valstybès lešu poreikis ivairioms socialinèms išmokoms mokèti bei darbuotojams perkvalifikuoti. Tai tik patvirtina ūkio finansinio išsekimo prognozavimo būtinybę ir aktualum Savahikis issekimo prognozavimo biturie in aktualumą. Savalaikis fnansinio issek provenci-

\section{IŠVADOS}

Biudžeto apribojimo sąvoka reiškia, kad ūkis turi padengti savo išlaidas iš pirminiu dotaciju ir pajamy Jei ūkis to ti savo isslaidas is pirminių dotaciju ir pajamǔ. Jei ükis to
nepadaro, finansiškai išsenka, todel negali išgyventi be iš-

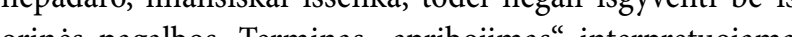
orines pagalbos. Terminas ,apribojimas interpretuojamas kaip likvidumo, mokno arba țsiskolinimo lygio riba, il kurios toleruotinas finansinès bükles blogèjimas. Mokslinèje literatūroje dažniausiai aptariamos dvi biudžeto apribojimo rūšys: minkštas ir kietas. Organizacija turi kietą biudžeto apribojimą tol, kol ji, siekdama sumažinti finansini išsekimą, negauna paramos iš kitų organizacijų, yra priversta mažinti veiklos apimtis arba nutraukti veiklą, jei finansinis sssekimas tęsiasi. Dažniausiai minkšto biudžeto apribojim formos pasireiškia, kai valdžia nepajegia surinkti mokesči valstybiniai bankai duoda pigias paskolas ar nepajegia su- rinkti palūkanų už paskolas. Valdžia, teikdama finansines injekcijas unkiams, siekia šalyje palaikyti neefektyviai aukšt Že lygt, kad isvengtu bedarbystes.

Žemès ukio subsidijavimas buvo rimta našta valstybès biudžetui tiek socialistinèje, tiek rinkos ekonomikoje. Socialistinèje ekonomikoje ši našta buvo būtina, siekiant užtikrinti gyventojams mažas maisto kainas, todèl minkštą biudžeto apribojimą laiké optimaliu fiskaliniu atsaku vyriausybi sekiančiu išvengti bedarbystess ir tẹsti socialini aprūpinim. Minkštas biudžeto apribojimas aktualus žemés ükyje,

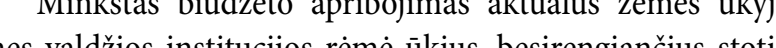
ES, kai gombs in

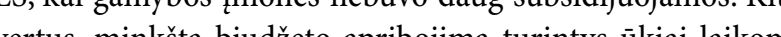

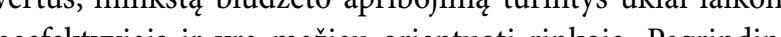
neefekty iais ir yra mażiau orientuoti rinkoje. Pagrindinis

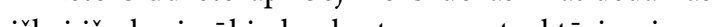

Ülis,

Ukis, kuris veikia kieto biudzeto apribojimo principu, turedamas dideliy nuostolity, nebegales toliau egzistuoti jo esama forma. Finansinis isssekimas atsiranda tada, kai ūkis negali ivykdyti issipareigojimu, del to priverstas parduoti turtą, atleisti dali darbuotoju, kreditoriai nebeturi perspektyv atgauti investicijų arba atsiskaitymai su kreditoriais gali būti rykdomi komplikuotai.

Mokslininkai pripažista, jog regioniné valdžia visada pageidauja kieto biudžeto apribojimo, nes kietą biudžeto aprbojimą turintys ūkiai laikomi konkurencingais ir galinčiais uždirbti pelną. ES struktūriniu fondų parama Lietuvai teikiama siekiant didinti ūkiu konkurencinguma, nors jos tikslas yra ne ekonominis efektyvumas, o žemdirbiu gyvenim ygio palaikymas.

Literatūra

1. Bakucs L. Z., Ferto I., Fogarasi J. 2009. Investment and financial constraints in Hungarian agriculture. Economics Letters. Vol. 104(3). P. 122-124.

2. Bates R. H. 1981. States and Markets in Tropical Africa: The Political Basis of Agricultural Policy. Berkeley: University of California Press.

3esfamille M., Lockwood B. 2008. Bailouts in federations. is a hard budget constraint always best? Internationa Economic Review. Vol. 49. No. 2 [ziurèta 2010-03-12]. Prieiga per internetą: http://onlinelibrary.wiley.com doi/10.1111/j.1468-2354.2008.00490.x/abstract;jsessionid =CC84B84CA4CCDA7F6F892DD5EBCDE4C4.d01t04 Breuille M. L., Madies T., Taugourdeau E. 2007. Fiscal fe deralism and soft budget constraint: does the nature of public spending matter? Economix, working paper [žiürèta 2010-09-15]. Prieiga per interneta: http://economix.fr/pdf/ dt/2007_WP_EcoX_2007-16.pd

Deft 2000 . Softbudget constraints and transition. In: Maskin E., Simonovits A. (eds.). 
Planning, Shortage, and Transformation: Essays in Honor of Janos Kornai. MIT press.

6. Janus T. 2009. Aid and the soft budget constraint. Review of Development Economics. Vol. 13(2). P. 264-275 [žiūrèta 2010-09-15]. Prieiga per internetą: http://onlinelibrary.wiley.com/doi/10.1111/j.1467-9361.2008.00485.x/full

7. Konings J., Rizov M., Vandenbussche H. 2003. Investment and financial constraints in transition economies: micro evidence from Poland, the Czech Republic, Bulgaria and Romania. Economics Letters. No. 78. P. 253-258 [žiūrèta 2011-05-06]. Prieiga per internetą: http://wase.urz.unimagdeburg.de/evans/Journal\%20Library/Problems\%20 of $\% 20$ Economic\%20Transition/Investment $\% 20 \mathrm{in} \% 20$ transition\%20economies.pdf

8. Kornai J. 1986. The soft budget constraint. Kyklos. Vol. 39(1). P. 3-30 [žiūrèta 2010-03-13]. Prieiga per internetą: http:// www.kornai-janos.hu/Kornai1986\%20The\%20Soft\%20 budget\%20Constraint\%20-\%20Kyklos.pdf

9. Kornai J. 2001. Hardening the budget constraints: the experience of the post socialist countries. European Economic Review. No. 45. P. 1573-1599, [žiūrèta 2011-05-06]. Prieiga per internetą: http://www.sciencedirect.com/science/article/pii/S0014292101001003

10. Kornai J., Maskin E., Roland G. 2003. Understanding the soft budget constraint. Journal of Economic Literature. Vol. XLI. P. 1095-1136 [žiūreta 2011-05-06]. Prieiga per internetą: http://www.nyu.cz/portal_memberdata/oschneider/pdf-schneider/Week3.pdf

11. Lerman Z. 2008. Farm debt in transition: the problem and possible solutions. Policy Studies on Rural Transition. No. 2. FAO Regional Office for Europe and Central Asia.

12. Lerman Z., Csaki C., Feder G. 2004. Evolving farm structures and land use patterns in former socialist countries. Quarterly Journal of International Agriculture. Vol. 43. No. 4. P. 309-335 [žiūrèta 2011-04-29]. Prieiga per internetą: http://departments.agri.huji.ac.il/economics/en/ publications/published_papers/2004/lerman-evolving.pdf

13. Maskin E., Xu C. 2001. Soft budget constraint theories: From centralization to the market. Economics of Transition. Vol. 9(1). P. 1-27 [žiūrèta 2011-04-06]. Prieiga per internetą: http://onlinelibrary.wiley.com/ doi/10.1111/1468-0351.00065/abstract

14. Perotti E. C. 1993. Bank lending in transition economies. Journal of Banking and Finance. Vol. 17. P. 1021-1032.

15. Qian Y., Roland G. 1998. Federalism and the soft budget constraint. The American Economic Review. Vol. 88. No. 5. P. 1143-1163.

16. Raiser M. 1997. Soft budget constraints and the fate of economic reforms in transition economies and developing countries. Tübingen. Germany: Mohr.

17. Rizov M. 2008. Corporate capital structure and how soft budget constraint may affect it. Journal of Economic Surveys. Vol. 22. No. 4. P. 648-684.

18. Robinson J. A., Torvik R. 2006. A political economy theory of the soft budget constraint. Working Paper. No. 12133 [žiūrèta 2011-04-06]. Prieiga per internetą: http://www. nber.org/papers/w12133
19. Schaffer M. 1998. Do firms in transition economies have soft budget constraints? A reconsideration of concepts and evidence. Journal of Comparative Economics. Vol. 26. P. 80103.

20. Segal I. 1998. Monopoly and soft budget constraint. RAND Journal of Economics. Vol. 29(3). P. 596-609.

21. Shleifer A., Vishny R. W. 1994. Politicians and firms. Quarterly Journal of Economics. Vol. 109. No. 4. P. 9951025.

22. Skoog G. E. 2000. The Soft Budget Constraint - The Emergence, Persistence, and Logic of an Institution. Dordrecht, Nethelands: Kluwer Academic Publishers.

23. Trakelis D. 2007. Europos Sąungos bendrosios žemès ūkio politikos raidos perspektyvos ir Lietuvos interesai. Politologija. Nr. 4(48), [žiūrèta 2011-04-06]. Prieiga per internetą: http://www.leidykla.vu.lt/fileadmin/ Politologija/48/87-113.pdf

24. Vitunskienè V. 2008. Agrarinés politikos ekonominiai ir socialiniai efektai Lietuvoje. Habilitacijos procedūrai teikiamų mokslo darbų apžvalga. Kaunas.

\section{Vaida Stulpinienè}

\section{BUDGET CONSTRAINT AND FARM FINANCIAL DISTRESS}

\section{Summary}

A budget constrained farm must bear its own costs of initial grant and income. If a farm fails to do so, when facing financial distress it cannot survive without outside help. The term "constraint" is interpreted as the liquidity, solvency or leverage boundary to the tolerable financial situation. The scientific literature generally considers two types of budget constraints: soft and hard. A budget constraint organization is limited to a hard budget constraint until it receives support from other organizations in order to reduce financial distress, and is forced to reduce the volume of business or cease operations if financial distress continues. The most common form of soft budget constraints occurs when the government fails to collect taxes, state-owned banks give loans at low cost or are unable to collect interest on loans. The purpose of government financial support is to maintain inefficient high level of work in order to avoid unemployment.

Despite large expenditure for agricultural support in the European Union (EU), farms still go to financial distress. A farm which operates under hard budget constraint cannot for a large loss continue in its present form. Financial distress often occurs when a farm has chronic and serious losses and/or when it becomes insolvent with liabilities that are disproportionate to the farm's assets.

Bankruptcy is generally considered to be a negative phenomenon in the market economy, a macroeconomic and a social problem. A farm next door to bankruptcy cannot pay to creditors; it is forced to lay off workers, which results in increasing unemployment, increasing the need for public funds to pay various social benefits and job retraining resources. The financial failure of a farm causes substantial losses to its shareholders, economy and society as a whole.

Key words: budget constraint, financial distress, farm 